\title{
Application for awards in 2021
}

C The Ichthyological Society of Japan 2020

The Ichthyological Society of Japan (ISJ) annually presents the Young Ichthyologist Award and the Best Article Award to an eminent young ichthyologist and to authors of articles published in Ichthyological Research or in the Japanese Journal of Ichthyology, in appreciation of their achievement and contribution to ichthyology. Members of ISJ are strongly encouraged to apply for these awards.

\section{The Young Ichthyologist Award 2021}

This award is given to an ichthyologist who is less than 40 years of age as of 31 December 2020. Nominees must be society members. The prize winner is asked to make a speech on her or his achievements in ichthyology at a plenary session of the ISJ meeting 2021. The winner receives 50,000 yen and traveling expenses (up to 150,000 yen).

\section{The Best Article Award 2021}

This award is given for an article published in Ichthyological Research Vol. 65(1)-67(4) or in the Japanese Journal of Ichthyology Vol. 65(1)-67(2). To be eligible as nominees, the first or corresponding author of the article must be a member of ISJ. Awards may be given for two or three articles from different research fields.

\section{Submission guideline}

The items listed below should be electronically submitted to the secretary of ISJ by 21 December 2020. In cases in which a nominee has no recommender, self-recommendation is possible.

\section{The Young Ichthyologist Award 2021}

- Curriculum vitae

- Recommendation letter

- List of research articles

- List of social and educational activities

- Copies of representative articles (maximum five)

- Addresses of nominee and recommender

\section{The Best Article Award 2021}

- Nominated article

- Recommendation letter with summary of article

- Addresses of nominee and recommender

To submit a nomination, please contact:

Dr. Katsutoshi Watanabe, Director, ISJ

Division of Biological Sciences, Graduate School of Science, Kyoto University, Kitashirakawa-Oiwakecho, Sakyo, Kyoto 606-8502, Japan

Tel \& Fax: + 81-75-753-4079

E-mail:watanak@terra.zool.kyoto-u.ac.jp

Publisher's Note Springer Nature remains neutral with regard to jurisdictional claims in published maps and institutional affiliations. 